\title{
A novel single nucleotide polymorphism (SNP) of the IGF1R gene and the association with growth traits in yak (Brief Report)
}

\author{
Ein neuer Einzelnukleotid-Polymorphismus (SNP) des IGF1R Gens \\ und die Assoziation mit Wachstumsmerkmalen beim Yak (Brief Report)
}

CHUNNIAN LIANG ${ }^{1,2}$, PING YAN², YUNI YAO², JIE PEI ${ }^{2}$, XIAN GUO ${ }^{2}$, YUFENG ZENG ${ }^{2}$, PENGJIA BAO² and MIN CHU²

${ }^{1}$ Gansu Agricultural University, Lanzhou, Gansu, People's Republic of China, ${ }^{2}$ Lanzhou Institute of Animal Science and Veterinary Pharmaceutics, Chinese Academy of Agricultural Sciences, Lanzhou, Gansu, People's Republic of China

\section{Background}

The insulin-like growth factor-I (IGF1) is a peptide growth factor that exerts mitogenic and metabolic activities, which are regulators of growth, survival and cell differentiation in a number of cell and tissue types. To elicit its effects, IGF1 must bind its receptors. The insulinlike growth factor 1 receptor (IGF1R) is similar to insulin receptor (INSR) and it mediates the growth-promoting effect of IGF1. The IGFIR gene, therefore, was selected as a biological candidate gene for growth, body composition, metabolic, and skeletal traits in animals (ROTHSCHILD et al. 1997). By now, no polymorphism of yak (Bos grunniens) IGF1R gene is reported. In the present paper, the partial exon 1 region of IGF1R was screened to detect the SNPs in Chinese yak breeds. Associations of SNP of IGF1R with growth traits were analysed.

\section{Procedure}

\section{Primer sequences}

As any of yak IGF1R gene sequences was not available, the primer pairs were designed based on bovine partial IGF1R gene (acc. no. NM174305).

\section{5'-ACC CGC CAA GAA ATT GTT TC-3' \\ 5'-GGC TCC TCC ATA CTT CCT GTA-3'}

\section{$P C R$ conditions}

$50 \mathrm{ng}$ of genomic DNA in a $20 \mu \mathrm{l}$ reaction containing $1.5 \mathrm{mM} \mathrm{MgCl} 2,0.2 \mathrm{mM}$ of each dNTP, $0.5 \mathrm{U}$ of Taq DNA polymerase (TaKaRa, China) and $0.4 \mu \mathrm{M}$ of each primer. The cycling protocol conditions included an initial denaturation cycle at $94^{\circ} \mathrm{C}$ for $5 \mathrm{~min}$, followed by 30 cycles of denaturation at $94^{\circ} \mathrm{C}$ for $1 \mathrm{~min}$, annealing at $57.5^{\circ} \mathrm{C}$ for $30 \mathrm{~s}, 72^{\circ} \mathrm{C}$ for $45 \mathrm{~s}$. Then, the amplified products were subjected to a final extension at $72^{\circ} \mathrm{C}$ for $10 \mathrm{~min}$. Polymorphism of $I G F 1 R$ was detected by SSCP in $12 \%$ PAGE in constant voltage (200V) for $12-15 \mathrm{~h}$ after its PCR products was denatured $10 \mathrm{~min}$ at $98^{\circ} \mathrm{C}$. The gel was stained with silver nitrate and visualized with $2 \%$ 
$\mathrm{NaOH}$ solution (supplied with $0.1 \%$ formaldehyde) (PAN et al. 2007). The PCR fragments from different SSCP patterns were subcloned and sequenced.

\section{Result}

A novel SNP was discovered in the exon 1 region of the IGF1R gene among 404 unrelated one-year-old animals which belonged to five yak breeds in China (Datong yak, 72; Tianzhu White yak, 111; Gannan yak, 133; Qinghai Plateau yak, 70; Xingjiang yak, 50). Gene and genotype frequencies of the discovered SNP were shown in Table 1. According to acc. no. BTU33122, the SNP was at nt437 within exon 1 of the coding sequence, but caused no amino acids exchange.

Table 1

Allele and genotype frequencies of PCR-SSCP at exon 1 region of IGFIR gene in five populations Relative Häufigkeit von Allelen und Genotypen einer PCR-SSCP im Exon 1 des IGF1R Gens in fünf Yak-Populationen

\begin{tabular}{|c|c|c|c|c|c|c|c|c|c|c|}
\hline \multirow[t]{2}{*}{ Breed } & \multirow[t]{2}{*}{$\mathrm{N}$} & \multicolumn{3}{|c|}{$\begin{array}{l}\mathrm{N} \text { of each } \\
\text { genotype }\end{array}$} & \multicolumn{3}{|c|}{$\begin{array}{l}\text { Genotypic } \\
\text { frequencies }\end{array}$} & \multicolumn{2}{|c|}{$\begin{array}{c}\text { Allelic } \\
\text { frequencies }\end{array}$} & \multirow{2}{*}{$\begin{array}{c}H W \\
\text { equilibrium } \\
\mathrm{x}^{2} \text {-test }\end{array}$} \\
\hline & & $A A$ & $A B$ & BB & $\mathrm{AA}$ & $A B$ & BB & A & B & \\
\hline Datong yak & 72 & 30 & 33 & 9 & 0.4166 & 0.4583 & 0.1250 & 0.6458 & 0.3542 & 0.0012 \\
\hline Tianzhu White yak & 111 & 50 & 51 & 10 & 0.4505 & 0.4595 & 0.0901 & 0.6802 & 0.3198 & 0.2250 \\
\hline Gannan yak & 101 & 59 & 33 & 9 & 0.5842 & 0.3267 & 0.0891 & 0.7475 & 0.2525 & 1.8240 \\
\hline Qinghai Plateau yak & 70 & 18 & 42 & 10 & 0.2570 & 0.6000 & 0.1429 & 0.5571 & 0.4429 & 3.2561 \\
\hline Xingjiang yak & 50 & 14 & 33 & 3 & 0.2800 & 0.6600 & 0.0600 & 0.6100 & 0.3900 & 7.497 \\
\hline
\end{tabular}

The SNP found in the yak IGF1R gene enable to conduct association analyses in order to evaluate the SNP as a genetic marker for breeding. As IGF1R binds IGFs which has effects on growth and reproduction, the association of genotypes (the $C>A$ of exon I) with growth traits were analysed in yak (Table 2). The associations were analysed by the least-squares method as applied in the general linear model (GLM) procedure of SPSS according to the following statistical model:

$$
y_{i j k}=\mu+B_{i}+S_{j}+M_{k}+e_{i j k}
$$

with $y_{i j k}$ is the studied traits, $\mu$ is the overall mean; $B_{i}$ is the fixed effect of breed, $S_{j}$ is the fixed effect of sex, $M_{k}$ is the IGF1R genotype effect, $e_{i j k}$ is the random residual effect. The result indicated the different genotype of IGF1R exon 1 had a significant effect on traits including of body weight, body height, body slanting length $(P<0.05)$, but the genotype did not affected on cannon circumference and heart girth. This result provoked the IGF1R gene as important candidate gene for production trait. 
Table 2

Effects of different genotypes of the exon 1 SNP of IGF1R Gene on production traits Effekte verschiedener Genotypen des Exon 1 SNP im IGF1R Gen auf Produktionsmerkmale

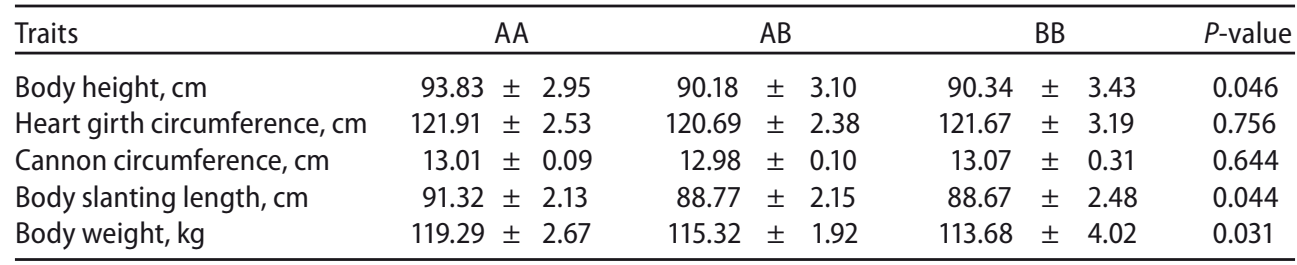

\section{Acknowledgements}

This study was supported by the National 863 Program of China (No. 2008AA10Z137), Central Public-interest Scientific Institution Basal Research Fund (No. BRF100101), National Beef Industry Technical System (No. MATS-Beef Cattle system), Key Technology Program from Gansu Province (No. 0801NKDA036).

\section{References}

Rothschild MF, Soller M (1997) Candidate gene analysis to detect traits of economic importance in domestic livestock. Probe 8, 13-20

Pan CY, Lan XY, Chen H, Hua LS, Guo YK, Zhang B, Lei CZ (2007) Five novel single nucleotide polymorphisms (SNPs) of the prophet of PIT1 (PROP1) gene in bovine. Arch Tierz 50, 421-3

Received 25 March 2010, accepted 21 July 2010.

Corresponding author:

YAN PING

email: pingyan@sohu.com.cn

Lanzhou Institute of Animal Science and Veterinary Pharmaceutics, Chinese Academy of Agricultural Sciences, Lanzhou, Gansu 730070, People's Republic of China 